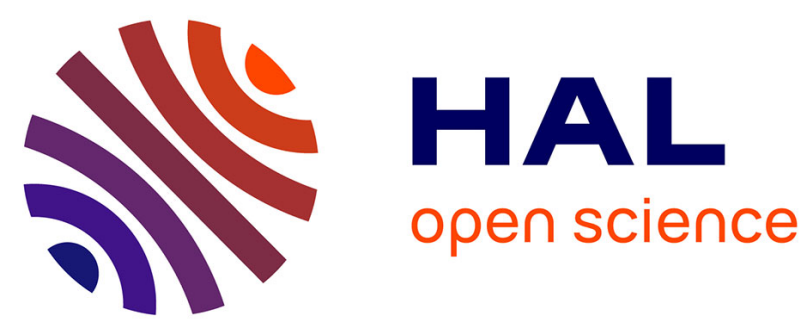

\title{
Shallow vent architecture during hybrid explosive-effusive activity at Cordón Caulle (Chile, 2011-12): Evidence from direct observations and pyroclast textures
}

C. Ian Schipper, Jonathan M. Castro, Hugh Tuffen, Mike R. James, Penelope How

\section{To cite this version:}

C. Ian Schipper, Jonathan M. Castro, Hugh Tuffen, Mike R. James, Penelope How. Shallow vent architecture during hybrid explosive-effusive activity at Cordón Caulle (Chile, 2011-12): Evidence from direct observations and pyroclast textures. Journal of Volcanology and Geothermal Research, 2013, 262, pp.25-37. 10.1016/j.jvolgeores.2013.06.005 . insu-00840779

\section{HAL Id: insu-00840779}

https://hal-insu.archives-ouvertes.fr/insu-00840779

Submitted on 3 Jul 2013

HAL is a multi-disciplinary open access archive for the deposit and dissemination of scientific research documents, whether they are published or not. The documents may come from teaching and research institutions in France or abroad, or from public or private research centers.
L'archive ouverte pluridisciplinaire HAL, est destinée au dépôt et à la diffusion de documents scientifiques de niveau recherche, publiés ou non, émanant des établissements d'enseignement et de recherche français ou étrangers, des laboratoires publics ou privés. 


\title{
Shallow vent architecture during hybrid explosive-effusive activity at Cordón
}

Caulle (Chile, 2011-12): Evidence from direct observations and pyroclast textures

C. Ian Schipper ${ }^{1,2} *$, Jonathan M. Castro ${ }^{3}$, Hugh Tuffen ${ }^{4}$ Mike R. James ${ }^{4} \&$ Penelope How $^{4}$

${ }^{1}$ School of Geography, Environment and Earth Sciences, Victoria University, PO Box 600, Wellington 6140, New Zealand

${ }^{2}$ Institut des Sciences de la Terre (ISTO), Centre National de la Recherche Scientifique (CNRS), l’Université d'Orléans, 1a rue de la Férollerie, Orléans Cedex 2, 45071,

France

${ }^{3}$ Institute of Geosciences, University of Mainz, Mainz, Germany

${ }^{4}$ Lancaster Environment Centre, Lancaster University, UK

*Corresponding author: schipper.ian@gmail.com

\begin{abstract}
In June 2011, an eruption of rhyolite magma began at the Puyehue-Cordón Caulle volcanic complex, southern Chile. By January 2012, explosive activity had declined from sustained pyroclastic (Plinian to sub-Plinian) fountaining to mixed gas and ash jetting punctuated by Vulcanian blasts. This explosive activity was accompanied by synchronous effusion of obsidian lava in a hybrid explosive-effusive eruption. Fortuitous climatic conditions permitted ground-based observation and video recording of transient vent dynamics as well as real-time collection of proximal juvenile ash as it sedimented from the active plume. The main eruptive vent complex and site of lava effusion was represented by two loci of Vulcanian blasts within a
\end{abstract}


single tephra cone containing a pancake-shaped proto-lava dome. These blast loci each consisted of clusters of sub-vents that expressed correlated shifts in eruption intensity, indicating the presence of partially connected and/or branching zones of high permeability within the upper conduit. Pyroclast textures were examined by X-ray computed microtomography and their permeability was modeled by lattice Boltzmann simulations. The porosity (39 to $67 \%$ ) and Darcian permeability $\left(3.1 \times 10^{-15} \mathrm{~m}^{2}\right.$ perpendicular to fabric to $3.8 \times 10^{-11} \mathrm{~m}^{2}$ parallel to fabric) of fine ash emitted during ash jetting indicates that the permeable zones comprised highly sheared, tube-like bubbly magma, and contrast with the low porosity ( 17 \%) and nul permeability of bombs ejected to hundreds of metres from the vent in Vulcanian blasts. Residual $\mathrm{H}_{2} \mathrm{O}$ content of ash $(0.14 \mathrm{wt} \%)$ and two bombs $(0.2-0.25 \mathrm{wt} \%)$, determined by Karl-Fischer titration indicate degassing of this pyroclastic material to near-atmospheric pressures. Ash textures and simple degassing/vesiculation models indicate the onset of permeability by ductile processes of shear-enhanced bubble coalescence in the upper 1 to $1.5 \mathrm{~km}$ of the conduit. Repeated ash jetting and Vulcanian blasts indicate that such ductile processes were not sufficiently effective to accommodate all degassing requirements, and additional brittle (e.g., fragmentation) events transiently assisted in maintaining an open-system degassing regime that permitted long-lived, hybrid explosive-effusive activity. The eruption at Cordón Caulle has provided an excellent opportunity to closely observe key processes of silicic volcanism.

Keywords: Vulcanian; explosive-effusive transition; permeability; rhyolite; obsidian; Puyehue-Cordón Caulle; tube pumice

\section{Introduction}


Eruptions of rhyolite magma occur infrequently, but their hazardous nature is clear from the abundant and widely dispersed deposits they produce. Examples such as Novarupta, Katmai (1912) are among the largest historic eruptions (e.g., Fierstein and Hildreth, 1992), and Earth's largest supervolcanoes such as Toba (Indonesia) (Chesner and Rose, 1991), Yellowstone (USA) (Christiansen and Blank Jr., 1972), and Taupo (New Zealand) (Walker, 1980; Wilson et al., 1995) are invariably rhyolitic. However, prior to the 2008 eruption of Chaitén Volcano (Chile) rhyolitic eruptions had not been directly observed (Castro and Dingwell, 2009). Although the interpretation of field relationships between eruptive units is invaluable for constraining the dynamics of unwitnessed eruptions, syneruptive observation is essential for elucidating fine-scale heterogeneities in the course of an individual eruption. Unless witnessed, important processes that are pertinent to the hazards associated with a given eruption (such as transient vent migrations, wallrock collapses, protracted explosive-effusive transitions, et cetera) will go unrecognized unless they leave distinct stratigraphic signatures that are not overprinted by continuing and subsequent eruptions and/or post-eruptive erosion. Furthermore, processes that appear in the rock record as discrete events, such as an explosive-effusive transition, may in reality have occurred over weeks to months; the difference being relatively insignificant in geological time, but absolutely imperative for the appropriate mitigation of impact on human lives and infrastructure during the eruption.

On June 4, 2011, an explosive eruption of rhyolite magma (Silva Parejas et al., 2012; Castro et al., 2013) began at the Puyehue Cordón-Caulle volcanic complex (PCCVC), southern Chile (Fig. 1a), marking the first eruption from this basaltic to rhyolitic massif since 1960 (Lara et al., 2004; Lara et al., 2006; Singer et al., 2008). Initial Plinian phases of the eruption produced columns reaching $>15 \mathrm{~km}$ high, the ash 
from which quickly circumnavigated the globe to cause widespread disruption to air traffic in the Southern Hemisphere. By mid-June, the continuing sub-Plinian explosive eruption was joined by synchronous effusion of lava (Silva Parejas et al., 2012).

The onset of vigorous lava effusion shortly after the eruption started (Silva Parejas et al., 2012), from the same vent(s) that continued to produce sub-Plinian ash columns (Castro et al., 2013), is one of the most important aspects of the 2011-12 eruption. Models of explosive-effusive transitions in silicic eruptions generally speak in terms of end-member activity separated in time and resulting from contrasting mechanisms (Eichelberger et al., 1986; Jaupart and Allègre, 1991; Westrich and Eichelberger, 1994; Woods and Koyaguchi, 1994; Gonnermann and Manga, 2003), and do not allow for or consider there to be significant overlap. The hybrid activity at Puyehue-Cordón Caulle calls for an examination of how hybrid eruptive activity may be an important aspect of gradual shifts between explosive and effusive activity.

We use observations of eruptive activity and textural analysis of the pyroclasts produced to make qualitative analysis of vent and shallow conduit architecture during long-lived, near steady-state hybrid explosive-effusive activity at Cordón Caulle. Specifically, we investigate how micro-scale processes of vesiculation, shearing, strain localization, and permeability development create meso-scale vent structures that permit partial open-system degassing, and in turn control macro-scale eruption dynamics.

\subsection{The Puyehue-Cordón Caulle volcanic complex}

The Puyehue-Cordón Caulle Volcanic Complex is a group of eruptive centres in the Southern Volcanic Zone of the Chilean Andes (Fig. 1). Eruptions dating from the Pleistocene to the present have occurred from vents aligned in a $15 \times 4 \mathrm{~km}, \mathrm{NW}$ - 
SE ridge (Singer et al., 2008) that includes the $2236 \mathrm{~m}$ a.s.l. Puyehue stratocone, and at least 27 small eruptive centres concentrated along the $\sim 1500$ to 1793 m a.s.l. Cordón Caulle fissure system (Fig. 1b). The complex is unique in the Southern Andes for having erupted a wide range of magma types, ranging from basalts to rhyolites (Gerlach et al., 1988; Singer et al., 2008). The most recent eruptions have been rhyodacitic eruptions from Cordón Caulle, in 1921-22, and in 1960 following the magnitude $\mathrm{M}_{\mathrm{w}} 9.5$ Valdivia earthquake (Gerlach et al., 1988; Lara et al., 2004; Lara et al., 2006; Singer et al., 2008).

\section{Methods}

\subsection{Video collection and analysis}

We recorded the activity on January $4^{\text {th }}$ and $10^{\text {th }}, 2012$, with a Canon XF105 video camera ( 25 frames per second) in both visible light (normal) and uncalibrated infrared (IR) modes (Supplemetary Videos S1 and S2). The main observation point was $3.5 \mathrm{~km}$ from the active craters (Fig. 1b). We chose two representative 35-minute sequences ( $7 x \sim 5$-minute sequences) of video collected in IR during the night of January 4, and in normal mode during the day of January 10 for detailed time series logging of eruptive activity.

There are important caveats on the collective use of the daytime and nighttime video sequences to analyze the eruption dynamics. Shifts in plume colour denoting variations in fine particle concentration were clearly visible in the daytime footage (Fig. 2g-i) but only the very largest of individual bombs could be discerned.

Conversely, individual bombs were clear in infrared nighttime sequences (Figs. 2d-f), but transitions in plume colour were not obvious. Regardless, we use the daytime and nighttime sequences together to characterize the general eruption dynamics. This 
approach is based on the assumption that the incandescent, bomb-forming blasts observed in daytime footage have the same order of magnitude of eruptive intensity as those captured in the nighttime footage, which is supported by observations during a short period of twilight viewing conditions during which both shifts in plume colour and individual bombs could be seen (Fig. 2a-c).

\subsection{Samples}

Products of ash jetting were collected from the top of fieldwork tents $(3.8 \mathrm{~km}$ NNW of the vent) on the night of January 4. Bombs ejected by observed Vulcanian blasts could not be obtained for safety reasons, but two large ( $\leq 1 \mathrm{~m}$ diameter $)$ bombs with dense glassy exteriors and partially frothed interiors were collected from near one observation point (Fig. 1b). We assume that these bombs were erupted in similar Vulcanian fashion to those we observed, but that they were ejected at greater velocities since their ballistic trajectories reached $\sim 3$ times further from the vent than the bombs we observed. The collected bombs likely erupted in the first two weeks of activity, when video recordings showed large blocks estimated in some cases to be several tens of meters in diameter raining out of the pyroclastic column (e.g., Televisión Nacional de Chile video available at http://www.youtube.com/watch?v=v1qGEWKAFDQ). Although the earlier Plinian phases of this eruption are not strictly the topic of this paper, we include in our discussion observations from $\mu-c T$ scans of pumice lapilli collected by CIS and JMC in a July 2011 field campaign.

\subsection{X-ray computed microtomography ( $\mu-c T)$ imaging and analysis}

We used a Phoenix Nanotom 180 X-ray computed microtomograph $(\mu$-cT) at l'Université d'Orléans to examine vesicle textures in juvenile ash and subvolumes of 
bomb material. Totals of 1000-2300 micrographs of each sample were collected during $360^{\circ}$ rotation, using a tungsten filament and molybdenum target. Operating voltages were in the range 80 to $100 \mathrm{kV}$, with currents of 50-90 nA. Voxel edge lengths ranged from $\sim 0.78 \mu \mathrm{m}$ (ash) to $14 \mu \mathrm{m}$ (bomb). 3D tomographs were calculated from the micrographs using an offline PC microcluster running Phoenix reconstruction software.

We measured sample porosity $(\phi)$ with Image J software by thresholding subvolumes from greyscale $\mu-c T$ image stacks to isolate void space. We then used the lattice Boltzmann flow simulation routine prepared by Degruyter et al. (2010a) to calculate Darcian permeability parallel to fabric $\left(k_{/ /}\right)$and in two orthogonal directions normal to fabric $\left(k_{\perp}\right)$. Degruyter et al. (2010a) used natural pumice with fabrics similar to those examined in this study to develop their code. They found that in order for permeability calculations to be accurate, scan resolutions needed to be sufficiently high to capture bubble walls and void space in the given sample, and the computational representative elementary volume (REV) needs to be large enough to ensure that a statistically valid volume is analyzed $\left(\mathrm{REV}>256^{3}\right.$ voxels for their natural pumice). We examined a subset of ash samples by scanning electron microscope (SEM) up to 2000x magnification to verify that $\mu$-cT resolution was sufficient to capture bubble walls and vesicles, and kept REV as large as possible. Due to the elongate morphology of the ash particles (see Section 3.3), REV dimensions approached the $\sim 256$ pixel minimum perpendicular to fabric, but could be kept longer ( $\leq 500$ pixels) parallel to fabric. Periodic tests by synthetically increasing the effective scan resolutions and REV with the ImageJ transform plugin did not change the calculated permeabilities. 


\subsection{Karl-Fischer titration}

We measured the $\mathrm{H}_{2} \mathrm{O}$ contents of pyroclastic material by Karl Fischer Titration (KFT; Westrich, 1987; Behrens, 1995). We handpicked 200 mg of crystalfree glass shards from fine ash to ensure that no crystals were included in the analysis. We then ground these to a fine powder $(\sim 100-300 \mu \mathrm{m})$ with an agate mortar and pestle. Powders were stored in a furnace at $100{ }^{\circ} \mathrm{C}$ to remove adsorbed water, and were then loaded into platinum dishes and inserted into the muffle furnace where they were heated to $1000{ }^{\circ} \mathrm{C}$ and held there for about 10 minutes, which for the fine powders is sufficient to achieve complete degassing (Westrich, 1995). Post analysis inspection of the samples indicated that they melted completely during the analysis conditions and were then devoid of vesicles. The analytical uncertainty on the results is estimated to be about $0.01 \mathrm{wt} . \%$. A duplicate analysis of a glassy bomb sample was made by FTIR and found to be identical within the analytical error of the result determined by KFT (for FTIR method see Castro et al., 2013).

\section{Results}

\subsection{Source of activity}

At the time of our observations, activity was proceeding from a $\sim 400 \mathrm{~m}$ diameter, $\sim 50 \mathrm{~m}$ high tephra cone at approximately $40^{\circ} 32^{\prime} \mathrm{S}, 72^{\circ} 08^{\prime} \mathrm{W}$ and $1500 \mathrm{~m}$ above sea level (Fig. 1). The tephra cone was horseshoe shaped, breached to the NW side (Fig. 1d), and contained two distinct loci of explosive activity that we subsequently refer to as the NW and SE vents (Fig. 1c). A GeoEye Foundation satellite image from July 3, 2011 (Fig. 1c) shows that earlier in the eruption, the vent region comprised two partly-overlapping cones aligned in a $\mathrm{N} 18^{\circ} \mathrm{W}$ trend that intersects the main Puyehue stratocone summit (Fig. 1b), $\sim 6 \mathrm{~km}$ to the SE. These had 
presumably coalesced to form the single tephra cone we observed. The tephra cone was also the source of lava effusion, and the source regions within the crater resembled pancake-shaped proto-domes, $\sim 50$ to $80 \mathrm{~m}$ in diameter, and exhibited slabby lava textures punctuated by arcuate cracks metres to tens of meters in length. Lava effused through the breach in the tephra cone in a 50 m wide channel that then spread to feed the larger flow field (Fig. 1d), which had an approximate volume of 0.2 to $0.3 \mathrm{~km}^{3}$, and was growing at a rate of 1 to $10 \mathrm{~m}^{3} \mathrm{~s}^{-1}$ (Silva Parejas et al., 2012; Tuffen et al., in review). Our observation point to the NW of the cone (Fig. 1b) allowed us to exploit the breach to clearly see into the NW vent, and point of lava effusion. Light NW winds were effective in preventing the plume from obscuring the view.

\subsection{Description of activity on January $4^{\text {th }}$ and $10^{\text {th }}, 2011$}

On January 4, explosive activity consisted of semi-continuous ash jetting punctuated by Vulcanian-like blasts (e.g., Morrissey and Mastin, 2000). There was a noteworthy hierarchical division of vent structures: the two main blast foci, the NW and SE "vents," each consisted of a series of smaller-scale structures we refer to as "sub-vents". Sub-vents were usually point discharge sources several metres in diameter, but were occasionally arcuate cracks up to 10 metres long. Although the plume from the NW vent mostly obscured the view, similar structures and activity seemed to control and characterize activity in the SE vent. SE vent activity was seemingly more intense, judging by the size and height of the ash plumes and the vigour of Vulcanian blasts (Fig. 2d-f). We tracked changes in eruptive intensity at individual sub-vents (Figs. 3 and 4), dividing activity types into: (0) inactivity (labeled "nul" in figures), with no apparent discharge from a visible sub-vent (as opposed to 
periods of "no data" when the sub-vent was obscured by the plume; Fig. 3); (1) gas jetting, with discharge of white, steam-rich plumes (e.g., Fig. 2a); (2) minor ash jetting, seen as a darkening of the discharged plume (e.g., Fig. 2b); (3) intense ash jetting, a qualitatively more intensive version of ash jetting with very dark plumes; and (4) Vulcanian blasts, with incandescent jetting and ejection of ballistic bombs (e.g., Fig. 2c). Figure 2a-c shows a transition through three regimes of increasing intensity under twilight conditions on January 4. Plumes from both the NW and SE vents combined in the tephra cone to produce a low gas-thrust region and sustained buoyant plume up to $2 \mathrm{~km}$ high. Activity was sufficiently persistent that there was always a plume present, in which individual pulses of varying intensity could be readily identified by variations in plume breadth and colour. Occasional inclined ash jets that climbed and overtopped the tephra cone were entrained upward into the main vertical portion of the plume.

On January 10, the activity was generally the same as one week earlier, although with somewhat lower intensity. The tephra cone housed the same vent and sub-vent structures, but blasts were less common and less vigorous. At any given time, 10 or more sub-vents could be seen in the NW vent. These had variable directionality and produced plumes with spatially and temporally variable ash contents. Disordered changes in sub-vent geometry included the widening and increasing height and vigour of gas+ash jets, but bomb-producing blasts were less frequently than one week earlier. Sometimes, rather than causing blasts, increased discharge was accommodated by the simultaneous or staggered opening of many additional sub-vents, at times defining curvilinear structures around the margins of the proto-dome lava (Fig. 2g-i). The combined plume from the NW and SE vents on January 10 still reached $\sim 1.5 \mathrm{~km}$ high, but did not maintain a strong gas-thrust region, and the plume would often collapse to 
fill the tephra cone. Directed pulses that overtopped the cone during this period were not re-entrained back into the central plume, but descended the outer slopes under gravity.

Some sub-vents had lifetimes of only seconds, opening momentarily to discharge gas or ash, but did not appear to re-open in the same position again within the entire observational period. These were especially common on January 10, when Vulcanian blast activity was diminished, and included the specific curvilinear discharge points shown in Figure 2i. Other sub-vents were frequently active and apparently long-lived. These were active for most of the observational period and many did not appear to have changed position over the week between observations. Two such long-lived point sources are shown in Figures 2a and $2 \mathrm{~g}$. These passed regularly from emitting gas to variable concentrations of ash, but even following the most vigorous Vulcanian blasts, in which the vent region was disrupted these subvents would rapidly re-occupy the same positions, and become visible once the plumes dispersed.

Video logs from selected daytime sequences from January 10 are shown in Figure 3 (a portion of Video 305 given as Supplementary Video S1), that track 6 subvents in the greater NW vent. Although at times erratic, some patterns of activity are apparent. Most noteworthy is the switching between periods of generally high intensity, and generally low intensity activity. For example, there is a greater frequency of blasts in Videos 305-307 than in Videos 301-303, and this is registered across sub-vents i-v. Similarly, there is distinct correlation between punctuated blast activity from sub-vents i-iii recorded in Video 304. The exception is in sub-vent vi, which shows a small burst of activity in Video 301, but not again afterwards. We note that this sub-vent is located outside the central region of the great NW crater, close to 
the tephra cone inner wall. The ash discharge from this particular sub-vent was particularly dark in colour, yet not notably intensive, and it may have been a simple gas discharge that entrained cold, dark-coloured ash material from the inner margins of the cone with which it interacted.

The general statistical information gained from the daytime video logging is plotted in Figure 4, considering combined activity from the series of sub-vents i-v (vi being largely inactive through most of the logged video sequences). The majority of eruption time is spent in periods of inactivity ("nul") and in minor ash jetting (Fig. 4a). The average duration of the inactive periods is more than twice as long as for the other types of activity (Fig. 4b), and inherent in this, although not explicitly shown, is that the episodes of minor ash jetting are the most frequent.

Changes in the style of activity rarely followed regular progressions of nul gas jetting - ash jetting - blast - nul - etc. More commonly, the transitions were irregular, as captured in Figure 4c, which shows histograms of the frequency with which types of activity would follow one another. Periods of inactivity, gas jetting, intensive ash jetting, and blasts all most frequently gave way to periods of minor ash jetting (Fig. 4c). Irregularity is also evidenced by the fact that any type of activity at times transitioned into any other type; for example, although inactivity usually transitioned to minor ash jetting, it occasionally transitioned directly to blasts (Fig. $4 c)$.

In IR video, it is difficult to distinguish activity between different individual sub-vents, but Vulcanian explosions can be easily attributed to either the NW or SE vent regions (Figs. 2d-f, 5; a portion of Video 208 given as Supplementary Video S2). To evaluate timelines of activity from the NW and SE vents (Fig. 5), we divide activity into (1) inactivity, (2) detectable activity (possibly equal to gas jetting, labeled 
“gas" in figures), (3) minor activity (possibly equal to ash jetting, labeled "ash-I"), and (4) major activity (bomb-forming blasts). The NW and SE vents frequently (but not ubiquitously) show coincident high-intensity blast events (Fig. 5b-c).

\subsection{Pyroclast textures, permeability, and $\mathrm{H}_{2} \mathrm{O}$ contents}

We set up our tents clean on the evening of January $4^{\text {th }}$ in negligible wind, and heard/monitored the deposition of a 1-2 mm thick layer of ash that collected during the night. Ash was poorly sorted but tended towards fine grain sizes $(<<0.1 \mathrm{~mm})$. It was mostly pumiceous (Fig. 6a-b), except for very rare but easily discernable chips of dense obsidian (Fig. 6c). All ash particles were nearly aphyric, with rare plagioclase microphenocrysts, consistent with the petrography of pumice erupted in the earlier Plinian phases of the 2011-12 eruption (Silva Parejas et al., 2012; Castro et al., 2013). The largest ash grains had a tube-like fabric that was obvious in hand sample; the fabric controlled particle morphology so that grains were up to $\sim 2.5 \mathrm{~mm}$ along fabric, but always much smaller ( 0.5 mm) normal to fabric (Fig. 6a,b,d).

Analyzed Ash grains $(n=17)$ have porosity ranging from 32 to $67 \%$. Darcian permeability parallel to fabric $\left(k_{/ /}\right)$ranges from $1.5 \times 10^{-12}$ to $3.8 \times 10^{-11} \mathrm{~m}^{2}$ (average $=$ $1.2 \times 10^{-11} \mathrm{~m}^{2}$ ), and permeability normal to fabric $\left(k_{\perp}\right)$ spans a much wider range, from $3.1 \times 10^{-15}$ to $4.4 \times 10^{-11} \mathrm{~m}^{2}$ (average $=4.3 \times 10^{-12} \mathrm{~m}^{2}$ ). With one exception (Table 1 ; tent16), permeability in the two calculated normal directions were within an order of magnitude of each other, and all are therefore plotted as an average $k_{\perp}$ in porositypermeability space (Fig. 7). Permeability along fabric is in most cases 1-2 orders of magnitude higher than normal to fabric, and this is apparent in streamline visualizations of lattice-Boltzmann gas flow models through tube-like pumice in the fabric-parallel (Fig. 6f) and fabric-normal (Fig. 6g) directions. 
Figure 7 shows porosity-permeability relationships, compared to the range of values measured in isotropic silicic pumice by Klug and Cashman (1996), and anisotropic tube pumice as reported by Wright et al. (2006; $k_{/ /}$only) and Degruyter et al. (2010b; $k_{/ / /}$and $k_{\perp}$ for the same clasts). Although some $k_{\perp}$ of the Cordón Caulle ash plot within the field defined by Klug and Cashman (1996), most tend toward higher permeability for a given porosity, and fabric-parallel permeabilities tend toward higher values still. Porosity and permeability measurements (Table 1; Fig. 7) allow us to examine one mechanism of brittle fragmentation, by calculating the bubble overpressures $\left(\Delta P_{\text {frag }}\right)$ that would have been required to fragment the bubbly melts represented by each pyroclast, following Mueller et al. (2008) (see caption to Table 1 for formulation). For ash, $\Delta P_{\text {frag// }}$ ranges from 5.7 to $12.5 \mathrm{MPa}$ (average $=8.9 \mathrm{MPa}$ ), and $\Delta P_{\text {frag } \perp}$ ranges from 3.7 to $9.8 \mathrm{MPa}$ (average $=5.7 \mathrm{MPa}$ ). A single scan of a portion of the bomb rim yielded porosity of $17 \%$, and nul permeability, which together indicate a $\Delta P_{\text {frag }}$ of 9.1 MPa (Table 1 ; Fig. 8).

Both the ash and bomb material are almost completely degassed to atmospheric pressure. Total $\mathrm{H}_{2} \mathrm{O}$ content of bulk ash material is $0.14 \mathrm{wt} \%$, and in the bomb rim is $0.20-0.25$ wt $\% . \mathrm{H}_{2} \mathrm{O}$ solubility in standard rhyolite melt (Newman and Lowenstern, 2002) indicates that the ash and bomb melts degassed to pressures $\left(P_{H 2 O}\right)$ of 0.19 and $0.37-0.54 \mathrm{MPa}$, respectively. For vesicle-free magma with density $\left(\rho_{m}\right)$ of $2300 \mathrm{~kg} \mathrm{~m}^{-}$ ${ }^{3}$, these pressures correspond to minimum magmastatic depth range of $\sim 8$ metres for ash and $16-23$ metres for bombs.

\section{Discussion}

For significant volumes of silicic magma to erupt effusively, there must be an effective open-system degassing mechanism by which exsolving volatiles can escape. 
In the case of Cordón Caulle, this mechanism had to become effective during, and to continue synchronously with, explosive activity. The long-lived, hybrid eruption style precludes the strict application of classical concepts such as the collapsing foam model (Eichelberger et al., 1986; Westrich and Eichelberger, 1994); but it gives insight into the structures and mechanisms that allow open-system volatile loss from ascending magma to keep pace with magma supply and degassing rates, leading to a significant proportion of the magma being erupted effusively and emplaced as silicic lava.

\subsection{Structural hierarchy, connectivity, and longevity}

The cones that developed early in the Plinian phase of the eruption (Fig. 1c), and then subsequently coalesced (Fig. 1d, 3a), were the products of two distinct centres of explosive activity roughly parallel to the dike-related fracture swarms formed in the eruption (Fig. 1c). The division of the vent activity into these separate loci continued up to and through the period of our observations. IR video (Fig. 2d-f) showed that blasts from the SE vent cast bombs in different trajectories than those from the NW vent, and to farther distances (Fig. 5a), which has implications for how Vulcanian eruption deposits are interpreted after activity has ceased. Commonly, bomb sizes can be measured in the field, and ballistic trajectory models applied to estimate their ejection velocities and driving pressures (Wilson, 1980; Turcotte et al., 1990; Woods, 1995; Alatorre-Ibargüengoitia et al., 2010). Such models require assumptions about the exact source location and ejection angle of the bombs. At Cordón Caulle, the assumptions of a single source with and symmetric distribution of ejection angles to derive driving pressures would result in larger than expected errors.

The frequent coincidence of high-intensity blast activity at the NW and SE vents (Fig. 5b-c) can be interpreted in two ways. It could mean that they represent 
outlets of two separate structures in which pressures evolve independently. In this case, near-simultaneous blast activity may result from a blast/ unloading event at one cluster partially weakening caprock on the separate but adjacent structure and causing its subsequent failure. Alternatively, the two vents could be two outlets branching from the same permeable structure at depth, so that escalating pressures in this common structure are manifested as explosive failures near-simultaneously at the surface. In this case, the regular occurrence of synchronous blasts from both vents (Fig. 5 b-c) suggests at least some advanced degree of connectivity in the shallow subsurface, and that time lags between blasts at different vents might relate to contrasting local permeabilities or lengths of permeable structures. Similarly, but at a smaller scale, the common coincidence of blast activity affecting different sub-vent structures (Fig. 3), suggests that the sub-vents are also multiple outlets from a common shallowly seated and branched structure. In this sense, the network of permeable pathways in the shallow conduit can be described as dendritic in nature: the NW and SE vent clusters, and the sub-vents within each cluster representing different hierarchical levels in the size of structural elements.

An important feature of the different structural elements in the vent complexes is their longevity, which denotes a relatively stable upper conduit structure. Segregation of the sites of explosive activity into NW and SE vents occurred early in the eruption, at least a month before our field campaign (Fig. 1c), and the finest-scale degassing outlets persisted in essentially the same locations within the lava effusing from the tephra cone for a minimum of weeks. Inherent in the longevity of the subvent structures is that they not only survive lava effusion, but also repeated Vulcanian blasts, when some portion of the upper carapace of lava is coarsely fragmented and 
ejected as bombs. During this activity the locations of main and sub-vents appear to remain essentially unchanged.

\subsection{Ductile and brittle permeability development}

The tube-like texture of ash discharged during the observed activity at Cordón Caulle (Fig. 6) is evidence that the ductile processes of bubble shearing and coalescence were important for establishing permeability. Tube pumice results from extensive elongation of bubbly magma (Marti et al., 1999), which significantly enhances bubble coalescence (Burgisser and Gardner, 2005; Okumura et al., 2006; Okumura et al., 2008; Okumura et al., 2009) and yields anisotropic void networks that have along-fabric tortuosity much lower, and permeability orders of magnitude greater (Fig. 6f-g), than cross-fabric (Wright et al., 2006; Wright et al., 2009; Degruyter et al., 2010b). We interpret the sub-vents viewed at Cordón Caulle (Figs. 2, 3) to be the surface expressions, or outlets, of sheared zones of magma containing stretched bubbly melt with a texture comparable to the highly permeable tube-like ash (Fig. 6). These zones operated as preferential outgassing pathways, and permitted a degree of open-system degassing during observed periods of gas discharge (Fig. 2).

The ejection of pyroclastic material, both in ash jetting and Vulcanian blasts, is evidence of brittle failure of both bubbly and dense material. Ash jetting sequences represent the brittle disruption (Marti et al., 1999) of the frothy tube-like network from within the degassing structures that fed the sub-vents, and is accompanied by entrainment of minor particles of the comparatively denser surrounding walls (Fig. 6c). During the shift from gas jetting to ash jetting, the degassing structures would have gone from being networks of bubbly magma to open cracks or fissures with gas + ash mixtures moving through them. These are akin to short-lived tuffisite veins 
(Stasiuk et al., 1996; Cabrera et al., 2011; Castro et al., 2012b), with widths spanning metres to less than a millimetre. Thus, while the ductile tube-like magma allowed lower-magnitude but longer-lived gas transfer, total outgassing was periodically bolstered by higher-magnitude but shorter-lived gas transfer through brittle fractures. The shifts in eruptive style we observed are then illustrative of the previously recognized balance between ductile and brittle processes that can maintain overall open-system degassing of silicic systems (Stasiuk et al., 1996; Tuffen et al., 2003; Castro et al., 2012b).

Calculations based on equilibrium degassing and vesiculation of rising magma allow depth estimates to be placed on key processes. Using the petrological constraints on the storage conditions of Cordón Caulle magma determined by Castro et al. (2013): $P=50-100 \mathrm{MPa}(2.5-5 \mathrm{~km}), T=\sim 896{ }^{\circ} \mathrm{C}$ and negligible $\mathrm{CO}_{2}$, we calculate the porosity versus pressure (depth) evolution for equilibrium degassing of $\mathrm{H}_{2} \mathrm{O}$, using the formulation of Burgisser and Gardner (2005; their equation A8) (Fig. 8).

The porosity of ash and bomb samples are much lower than the equilibrium porosities associated with their $P_{H 2 O}$ (Table 1; Fig. 8). Assuming that postfragmentation degassing was negligible because of the small size of ash and because $\mathrm{H}_{2} \mathrm{O}$ was measured in quenched rims of the bomb, they must therefore have degassed in an open-system. For ash, the structures required for this are evident in tube-like pore network and its along-fabric permeability (Figs. 6, 7). The bomb-forming magma probably had achieved higher porosity and permeability at depth (Fig. 8) but subsequently collapsed. Textural evidence of such collapsed foams are common in vesicle-poor obsidians from other locations (e.g., Krafla (Iceland); Tuffen and Castro, 2009), and could yield the bomb material with both low- $\mathrm{H}_{2} \mathrm{O}$ and low porosity. 
Shear enhances bubble coalescence even in magma that has not yet achieved high porosity (Burgisser and Gardner, 2005; Okumura et al., 2006; Okumura et al., 2008; Okumura et al., 2009; Okumura et al., 2013), so that ductile processes of permeability onset begin to be effective at significant conduit depths. The onset of shear-enhanced coalescence and permeability has been experimentally shown to occur at $\sim 30 \%$ porosity (Okumura et al., 2006; Okumura et al., 2008; Okumura et al., 2009). Assuming the magma had negligible porosity at its $2.5-5 \mathrm{~km}$ storage zone, an equilibrium porosity of $30 \%$ would be attained at minimum depths between $~ 1020$ and $1690 \mathrm{~m}$ (Fig. 8). We suggest that these depths may correspond to the depth of penetration of the permeable degassing structures from the sub-vent outlets into the upper conduit of Cordon Caulle.

The requirement for significant shearing to have played a role in permeability development calls for an assessment of the spatial distribution of sub-vents observed at Cordon Caulle. Although gas discharged sporadically from the inner margins of the tephra cone (Fig. 2i), the outlets of the most vigorous and long-lived sub-vents were not concentrated in these regions (Fig. 3a). Thus, the most persistent of degassing structures do not appear to be along conduit walls, assuming that the proto-dome seen in the base of the tephra cone can be taken as a proxy for the conduit cross section at the point of intersection with the ground surface. This is of interest because conduit walls should be the regions of greatest shear, promoting the development of both ductile (Okumura et al., 2006; Okumura et al., 2008; Okumura et al., 2009; Okumura et al., 2013) and brittle (Gonnermann and Manga, 2003; Rust et al., 2004) permeability.

Assuming that the Cordón Caulle eruption was dike-fed (Castro et al., 2013), we can envision zones of high shear in the shallow conduit (Blake and Fink, 1987); 
where faster-rising, bubbly melt from directly below the vent confluences with slowerrising melt from outboard of the vent along the strike of the dike (see Fig. 7 of Castro et al., 2013). The distribution of degassing structures and their sub-vent outlets can then be partly explained because the dike-shaped conduit would have been feeding a relatively small point source of magma discharge. Okumura et al. (2009) discuss the importance of the ratio of conduit radius $(R)$ to length $(L)$ in determining the thickness of a shear-induced permeable zone that begins at conduit margins. As $R / L$ decreases, the width of the permeable zone increases. For Cordón Caulle, $R \sim 25 \mathrm{~m}$ and minimum $L$ (neglecting lateral flow in the dike) is 2500 to $5000 \mathrm{~m}$ (Castro et al., 2013), yielding $R / L$ of 0.01 to 0.005 , which should result in the magma that even at low porosity has shear-induced permeability over most of its cross section by the time it reaches the vent (see Fig. 6 of Okumura et al., 2009). At times before full cone coalescence, the effective $R$ would have been even lower, further promoting permeability development across the magma outlet's cross sectional area.

A second explanation for the degassing structure distribution is in shear localization. Shear localization has been recognized from textures over many scales in natural volcanic rocks (Stasiuk et al., 1996; Marti et al., 1999; Tuffen et al., 2003; Wright and Weinberg, 2009) and reproduced in recent experiments (Okumura et al., 2013). Wright and Weinberg (2009) identified this process at the microscopic scale in silicic pumice, and noted that once zones of high shear developed, feedback mechanisms would promote further deformation of these zones over homogenization of surrounding isotropic bubble networks. These lead to permeability-enhanced outgassing from some regions of magma, and prevent efficient outgassing of adjacent, non-sheared regions (Okumura et al., 2013). We suggest that the distribution of degassing structures observed at Cordón Caulle result in part from shear localization 
that promotes the development of channels of permeable, tube-like bubble networks dispersed within comparatively dense magma, or magma that foamed mostly isotropically and subsequently collapsed. No large lapilli were obtained during the observed activity, but lapilli produced during the opening Plinian phases of the eruption bear textural evidence of fine scale shear localization in bubbly portions of Cordón Caulle magma. Localized bands of crystal alignment (Fig. 9a) and in the finescale zonation between isotropic and tube vesicle textures (Fig. 9b). We present these textures as possible indications of precursory shear localization that may have led to the later development of more pervasive, permeable degassing structures that have their outlets at the sub-vents.

The shear and strain considerations mentioned above apply to processes in the upper 1 to $1.5 \mathrm{~km}$ (Fig. 8) subsurface at Cordón Caulle, but the shear regime in the vents would also have been strongly influenced by lava effusion. Studies on shear zonation during the extrusion of viscous lava domes provide some insight into dynamics at critical vent outlet zones (Buisson and Merle, 2002; Hale and Mühlhaus, 2007; Hale and Wadge, 2008); with the limitation that the extensive crystallization that strongly influences dynamics of andesitic domes (Hale and Wadge, 2008) would not have been a significant factor in the extrusion of the largely aphyric, rhyolitic (Castro et al., 2013) Cordón Caulle lava. Analogue experiments on dome cross sectional flow by Buisson and Merle (2002) indicate that the change from vertical flow up the conduit to horizontal flow away from the vent would have caused complex shear zonation in extruded portions of magma, with a narrow central zone directly above the vent experiences pure shear, and zones away from the narrow central zone experience complex patterns of simple and pure shear (Fig. 10). The latter of these regimes extends sub-horizontally to control down-flow lava emplacement dynamics 
(Merle, 1998; Castro et al., 2002). In the vent region, the transitions in shear and strain sense during vertical to horizontal extrusive flow appear to have had no effect on the consistency of vent or sub-vent locations. It is possible, however, that horizontal components of lava flow are partly responsible for periodically sealing the outlets of the sub-vent degassing networks (a "lid" flows over as a temporary seal), promoting overpressure buildup that could explain some of the more abrupt changes in sub-vent activity type (e.g., direct inactivity to blasts; Fig. 4c), while shifts in shear regime moving outboard from the central vent may have guarded against any long-term capping of the system, permitting long-lived continuation of hybrid activity.

\subsection{Variations in fragmentation style}

The low $P_{H 2 O}$ values of ash and bombs demonstrate that they was derived from shallowly-sourced magma. They do not indicate that explosive fragmentation proceeded as a disruptive front that propagated down into, and excavated, the conduit; possibly because the presence of highly permeable zones assisted in the attenuation of fragmentation wave propagation (Alidibirov and Dingwell, 2000). The large differences in porosity and permeability between the tube-like ash and dense pyroclastic bombs (Table 1, Fig. 7), and the difference in dynamics between ash jetting and Vulcanian blasts indicates that it is not appropriate to apply a single fragmentation criterion (Papale, 1999; Zhang, 1999; Alidibirov and Dingwell, 2000; Spieler et al., 2004) to the generation of all the different pyroclast types.

Ash generation due to fragmentation by bubble overpressure (Spieler et al., 2004; Mueller et al., 2008) runs contrary to the very low $\mathrm{H}_{2} \mathrm{O}$ contents and $P_{H 2 O}$ (Table 1; Fig 8). Had fragmentation of a tube-like bubbly melt network been driven by the calculated $\Delta P_{\text {frag }}$ (Table 1, Fig. 8), we would expect the ash to have retained $\mathrm{H}_{2} \mathrm{O}$ 
in the range of (0.78 to $1.17 \mathrm{wt} \%$ : Newman and Lowenstern, 2002), or re-absorbed a similar amount of $\mathrm{H}_{2} \mathrm{O}$ if the $\Delta P_{\text {frag }}$ had been achieved by re-pressurization of a previously degassed melt (Watkins et al., 2012). Instead, the elongate bubble fabrics denote fragmentation by high strain, as described for the formation of tube pumice (Marti et al., 1999). As strain in the bubbly melt increased, it went from deforming in ductile to brittle (e.g., failure) regimes (Marti et al., 1999; Papale, 1999). This process would be enhanced as shallow degassing/dehydration reduced melt viscosity (Giordano et al., 2008), and is most readily linked to the observed periods of ash jetting.

The phenomenon of Vulcanian blast activity belies a buildup of overpressure and sudden brittle failure (Morrissey and Mastin, 2000), rather than the continuum of strain accumulation that can be used to explain the stretching and failure of the ash (Marti et al., 1999). Bomb-forming blasts require overpressures from which a component is consumed in the fragmentation (Alatorre-Ibargüengoitia et al., 2010) of the low-porosity, low-permeability lava $\left(\Delta P_{\text {frag }} \sim 9.1 \mathrm{MPa}\right.$; Table 1 and Fig. $\left.6 \mathrm{~b}\right)$, with another large component transferred to kinetic energy in the imparting of momentum to the bombs (Wilson, 1980; Turcotte et al., 1990; Woods, 1995). The $\Delta P_{\text {frag }}$ required to fragment bomb-forming magma again exceeds the magmastatic pressures at the source depths of these melts, as indicated by their $\mathrm{H}_{2} \mathrm{O}$ contents and $P_{\mathrm{H} 2 \mathrm{O}}$ (Fig. 8). Therefore, the overpressures required for blast fragmentation cannot have been generated locally; i.e, at the shallow residence depth of the bomb-forming magma as it degassed, to be then released by the opening of tensile cracks in the lava carapace. The higher fragmentation pressures must be a consequence of gas fluxing from deeper in the conduit, perhaps in cycles of gas accumulation and release, as those observed by 
analysis of very long period signals during Vulcanian blasts at Popocatépetl, Mexico (Chouet et al., 2005).

\subsection{Summary of shallow vent architecture and its control on activity}

Figure 10 shows a schematic interpretation of the shallow vent architecture at Cordón Caulle during the observed activity. It is a key point that the bulk of the magma ascending in the main conduit eventually erupts effusively to feed the advancing lava flow and the vertical growth of the proto-lava carapace in the bottom of the tephra cone. This magma is cross cut by a branching network of permeable degassing structures, which are essentially sub-conduit zones of sheared, permeable, tube-like bubbly magma. The degassing structures have cross-sectional diameters on the scale of a few metres, and permit the efficient transfer of exsolved volatiles from depth-to-surface. They are interpreted to extend to greater than $1000 \mathrm{~m}$ depth in the conduit to the depth where shear-induced coalescence becomes important, and to propagate into the ascending magma by shear localization, so that they and their subvent outlets remain essentially stationary through extended periods of shallow-seated $(10-20 \mathrm{~m})$ Vulcanian blast activity. The transition from vertical to horizontal flow as lava extrudes from the vent may have a superficial effect of temporarily blocking subvents, which in turn may exacerbate overpressure buildup to generate Vulcanian blasts, but does not affect the deeper structures of permeable bubbly magma. The permeable pathways are transiently connected at shallow levels, and are self-organized into two main groups, which define the SE and NW vents that became established early in the 2011-12 eruption of Cordón Caulle.

Transitions from gas to ash to blast activity correspond to volatile exsolution and overpressure fluctuations in the conduit, which are manifested as gas supply 
fluctuations at the vent. Conceptually, a fluctuating gas supply explains the observed range of activity phenomena. (1) When gas supply is low, the permeable degassing structures of tube-like bubbly melt can accommodate the total gas flux, and gas jetting from sub-vents is the dominant activity observed. (2) As rates of volatile exsolution and gas flux start to exceed the carrying capacity of ductile permeability, bubbly magma starts to experience protracted strain by shear localization. When this is sufficient to move the melt from a viscous to brittle deformation regime, ash jetting and higher gas flux are observed. (3) If ash jetting is still not sufficient to accommodate the gas flux, and/or if the outlets of permeable structures have become capped by flowing lava, overpressure builds to drive brittle fragmentation and bomb ejection. The resulting open fracture networks greatly increase permeability for a short time, and allow rapid overpressure dissipation. (4) Under relieved pressure and gas supply, permeable networks (both ductile and brittle) begin to anneal to again reduce permeability and recommence the process of overpressure buildup.

\section{Conclusions}

The 2011-12 eruption of Cordón Caulle has provided an unprecedented opportunity to observe the hybrid explosive-effusive eruption dynamics that led to emplacement of a large obsidian lava flow during sustained pyroclastic venting. There is evidence for the interplay of both ductile and brittle processes of permeability development in achieving the long-lived open-system degassing regime required to generate the observed lava. Ductile processes include bubble coalescence, enhanced by shear, that result in hierarchical structures of bubbly, permeable magma, probably extending up to $1.5 \mathrm{~km}$ into the subsurface conduit. These structures permit the early escape of exsolving volatiles through permeable networks of connected bubbles. Brittle processes occur primarily in the very shallow vent region, and include 
fragmentation of both the bubbly magma and the surrounding dense magma. Brittle processes allow rapid transfer of overpressured volatiles, sporadically compensating for the gas-transfer limitations on the permeable bubble networks.

The observations presented here illustrate the heterogeneity of processes that work concurrently within an active explosive-effusive silicic conduit and vent. The range of activity and pyroclast textures shows that processes of textural evolution and fragmentation by several mechanisms occur cooperatively to accommodate the intense shear environment and degassing requirements of ascending rhyolitic magma. These results challenge our ability to accurately describe volcanic processes and eruptions using end-member terminology such as ductile or brittle, passive or active, and explosive or effusive.

\section{Acknowledgements}

C.I. Schipper acknowledges support from ERC grant 202844 under the European FP7, from Victoria University of Wellington, and from the Japan Society for the Promotion of Science. H. Tuffen acknowledges support from a Royal Society University Research Fellowship. We thank the BBC and especially Dr Ben Finney for loan of video camera equipment.

\section{References}

Alatorre-Ibargüengoitia, M.A., Scheu, B., Dingwell, D.B., Delgado-Granados, H. and Taddeucci, J., 2010. Energy consumption by magmatic fragmentation and pyroclast ejection during Vulcanian eruptions. Earth Planet Sci Lett, 291: 6069. (doi)10.1016/j.epsl.2009.12.051. 
Alidibirov, M. and Dingwell, D.B., 2000. Three fragmentation mechanisms for highly viscous magma under rapid decompression. J Volcanol Geotherm Res, 100: $413-421$

Behrens, H., 1995. Determinations of water solubilities in high-viscosity melts: An experimental study on NaAlSi2O8 and KAlSi3O8 melts. Eur J Mineral, 7: 905-920

Blake, S. and Fink, J.H., 1987. The dynamics of magma withdrawal from a density stratified dyke. Earth Planet Sci Lett, 85: 516-524

Buisson, C. and Merle, O., 2002. Experiments on internal strain in lava dome cross sections. Bull Volcanol, 64: 363-371. (doi)10.1007/s00445-002-0213-6.

Burgisser, A. and Gardner, J.E., 2005. Experimental constraints on degassing and permeability in volcanic conduit flow. Bull Volcanol, 67: 42-56. (doi)10.1007/s00445-004-0359-5.

Cabrera, A., Weinberg, R.F., Wright, H.M.N., Zlotnik, S. and Cas, R.A.F., 2011. Melt fracturing and healing: A mechanism for degassing of silicic obsidian. Geology, 39: 67-70. (doi)10.1130/G31355.1.

Castro, J.M., Manga, M. and Cashman, K.V., 2002. Dynamics of obsidian flows inferred from microstructures: Insights from microlite preferred orientations. Earth Planet Sci Lett, 199: 211-226

Castro, J.M. and Dingwell, D.B., 2009. Rapid ascent of rhyolitic magma at Chaitén volcano, Chile. Nature, 461: 780-783. (doi)10.1038/nature08458.

Castro, J.M., Cordonnier, B., Tuffen, H., Tobin, M.J., Puskar, L., Martin, M.C. and Bechtel, H.A., 2012b. The role of melt-fracture degassing in defusing explosive rhyolite eruptions at volcán Chaitén. Earth Planet Sci Lett, 333-334: 63-69. (doi)10.1016/j.epsl.2012.04.024. 
Castro, J.M., Schipper, C.I., Amigo, A., Silva Parejas, C., Mueller, S., Jacob, D. and Militzer, A.S., 2013. Storage and eruption of near-liquidus rhyodacite magma at Cordón Caulle, Chile. Bull Volcanol, 75: 702. (doi)10.1007/s00445-013$0702-9$

Chesner, C.A. and Rose, W.I., 1991. Stratigraphy of the Toba Tuffs and the evolution of the Toba Caldera Complex, Sumatra, Indonesia. Bull Volcanol, 53: 343-356

Chouet, B., Dawson, P. and ARciniega-Ceballos, A., 2005. Source mechanism of Vulcanian degassing at Popocatépetl Volcano, Mexico, determined from waveform inversions of very long period signals. J Geophys Res, 110: B07301. (doi)10.1029/2004JB003524.

Christiansen, R.L. and Blank Jr., H.R., 1972. Volcanic stratigraphy of the quaternary rhyolite plateau in Yellowstone National Park. U.S. Geological Survey Professional Paper, 729B

Degruyter, W., Burgisser, A., Bachmann, O. and Malaspinas, O., 2010a. Synchotron X-ray microtomography and lattice Boltzmann simulations of gas flow through volcanic pumices. Geosphere, 6: 470-481. (doi)10.1130/GES00555.1.

Degruyter, W., Bachmann, O. and Burgisser, A., 2010b. Controls on magma permeability in the volcanic conduit during the climactic phase of the Kos Plateau Tuff eruption (Aegean Arc). Bull Volcanol, 72: 63-74. (doi)10.1007/s00445-009-0302-x.

Eichelberger, J.C., Carrigan, C.R., Westrich, H.R. and Price, R.H., 1986. Nonexplosive silicic volcanism. Nature, 323: 598-602. (doi)10.1038/323598a0.

Fierstein, J. and Hildreth, W., 1992. The plinian eruptions of 1912 at Novarupta, Katmai National Park, Alaska. Bull Volcanol, 54: 646-684 
Gerlach, D.C., Frey, F.A., Moreno-Roa, H. and Lopez-Escobar, L., 1988. Recent volcanism in the Puyehue-Cordón Caulle region, southern Andes, Chile (40.5 ${ }^{\circ}$ S): Petrogenesis of evolved lavas. J Petrol, 29: 333-382

Giordano, D., Potuzak, M., Romano, C., Dingwell, D.B. and Nowak, M., 2008. Viscosity and glass transition temperature of hydrous melts in the system CaAl2Si2O8-CaMgSi2O6. Chem Geol, 256: 203-215. (doi)10.1016/j.chemgeo.2008.06.027

Gonnermann, H.M. and Manga, M., 2003. Explosive volcanism may not be an inevitable consequence of magma fragmentation. Nature, 426: 432-435

Hale, A.J. and Mühlhaus, H.-B., 2007. Modelling shear bands in a volcanic conduit: Implications for overpressures and extrusion-rates. Earth Planet Sci Lett, 263: 74-87. (doi)10.1016/j.epsl.2007.08.026.

Hale, A.J. and Wadge, G., 2008. The transition from endogenous to exogenous growth of lava domes with the development of shear bands. J Volcanol Geotherm Res, 171: 237-257. (doi)10.1016/j.jvolgeores.2007.12.016.

Jaupart, C. and Allègre, C.J., 1991. Gas content, eruption rate and instabilities of eruption regime in silicic volcanoes. Earth Planet Sci Lett, 102: 413-429

Klug, C. and Cashman, K.V., 1996. Permeability development in vesiculating magmas; implications for fragmentation. Bull Volcanol, 58: 87-100

Lara, L.E., Naranjo, J.A. and Moreno, H., 2004. Rhyodacitic fissure eruption in Southern Andes (Cordón Caulle; 40.5S) after the 1960 (Mw: 9.5) Chilean earthquake: A structural interpretation. J Volcanol Geotherm Res, 138: 127138

Lara, L.E., Moreno, H., Naranjo, J.A., Matthews, S. and Pérez de Arce, C., 2006. Magmatic evolution of the Puyehue-Cordón Caulle Volcanic Complex (40 $\left.{ }^{\circ} \mathrm{S}\right)$, 
Southern Andean Volcanic Zone: From shield to unusual rhyolite fissure volcanism. J Volcanol Geotherm Res, 157: 343-366

Marti, J., Sorlano, C. and Dingwell, D.B., 1999. Tube pumices as strain markers of the ductile-brittle transition during magma fragmentation. Nature, 402: 650-653

Merle, O., 1998. Internal strain within lava flows from analogue modelling. J Volcanol Geotherm Res, 81: 189-206. (doi)10.1016/S0377-0273(98)00009-2.

Morrissey, M.M. and Mastin, L.G., 2000. Vulcanian eruptions. In: Sigurdsson, H., Houghton, B., McNutt, S.R., Rymer, H. and Stix, J. (Editors), Encyclopedia of Volcanoes. Academic Press, New York, pp. 463-476.

Mueller, S., Scheu, B., Spieler, O. and Dingwell, D.B., 2008. Permeability control on magma fragmentation. Geology, 36: 399-402. (doi)10.1130/G24605A.1.

Newman, S. and Lowenstern, J.B., 2002. VolatileCalc: a silicate melt-H2O-CO2 solution model written in Visual Basic for excel. Comp Geosci, 28: 597-604

Okumura, S., Nakamura, M. and Tsuchiyama, A., 2006. Shear-induced bubble coalescence in rhyolitic melts with low vesicularity. Geophys Res Lett, 33(L20316). (doi)10.1029/2006GL027347.

Okumura, S., Nakamura, M., Tsuchiyama, A., Nakano, T. and Uesugi, K., 2008. Evolution of bubble microstructure in sheared rhyolite: Formation of a channel-like bubble network. J Geophys Res, 113(B07208). (doi)10.1029/2007JB005362.

Okumura, S., Nakamura, M., Takeuchi, S., Tsuchiyama, A., Nakano, T. and Uesugi, K., 2009. Magma deformation may induce non-explosive volcanism via degassing through bubble networks. Earth Planet Sci Lett, 281: 267-274. (doi)10.1016/j.epsl.2009.02.036. 
Okumura, S., Nakamura, M., Uesugi, K., Nakano, T. and Fujioka, T., 2013. Coupled effect of magma degassing and rheology on silicic volcanism. Earth Planet Sci Lett, 362: 163-170. (doi)10.1016/j.eps1.2012.11.056.

Papale, P., 1999. Strain-induced magma fragmentation in explosive eruptions. Nature, 397: $425-428$

Rust, A.C., Cashman, K.V. and Wallace, P., 2004. Magma degassing buffered by vapour flow through brecciated conduit margins. Geology, 32(4): 349-352

Silva Parejas, C., Lara, L.E., Bertin, D., Amigo, A. and Orozco, G., 2012. The 20112012 eruption of Cordón Caulle volcano (Southern Andes): Evolution, crisis management and current hazards. EGU General Assembly Abstracts, 14(EGU2012-9382-2)

Singer, B.S., Jicha, B.R., Harper, M.A., Naranjo, J.A., Lara, L.E. and Moreno-Roa, H., 2008. Eruptive history, geochronology, and magmatic evolution of the Puyehue-Cordón Caulle volcanic complex, Chile. Geol Soc Am Bull, 120: 599-618. (doi)10.1130/B26276.1.

Spieler, O., Kennedy, B., Kueppers, U., Dingwell, D.B., Scheu, B. and Taddeucci, J., 2004. The fragmentation threshold of pyroclastic rocks. Earth Planet Sci Lett, 226: $139-148$

Stasiuk, M.V., Barclay, J., Carroll, M.R., Jaupart, C., Ratté, J.C., Sparks, R.S.J. and Tait, S.R., 1996. Degassing during magma ascent in the mule creek vent (USA). Bull Volcanol, 58: 117-130

Tuffen, H., Dingwell, D.B. and Pinkerton, H., 2003. Repeated fracturing and healing of silicic magma generate flow banding and earthquakes? Geology, 31: 10891092 
Tuffen, H. and Castro, J.M., 2009. The emplacement of an obsidian dyke through thin ice: Hrafntinnuhryggur, Krafla Island. J Volcanol Geotherm Res, 185: 352366. (doi)10.1016/j.jvolgeores.2008.10.021.

Tuffen, H., James, M., Castro, J.M. and Schipper, C.I., in review. Observations of rhyolite lava flow field evolution at Puyehue-Cordón Caulle, Chile.

Turcotte, D.L., Ockendon, H., Ockendon, J.R. and Cowley, S.J., 1990. A mathematical model of vulcanian eruptions. Geophys J Int, 103: 211-217

Walker, G.P.L., 1980. The Taupo Pumice: Product of the most powerful known (ultraplinian) eruption? J Volcanol Geotherm Res, 8: 69-94

Watkins, J.M., Manga, M. and DePaolo, D.J., 2012. Bubble geobarometry: A record of pressure changes, degassing, and regassing at Mono Craters, California. Geology, 40: 699-702. (doi)10.1130/G33027.

Westrich, H.R., 1987. Determination of water in volcanic glasses by Karl-Fischer Titration. Chem Geol, 63: 335-340.

Westrich, H.R. and Eichelberger, J.C., 1994. Gas transport and bubble collapse in rhyolitic magma: an experimental approach. Bull Volcanol, 56: 447-458

Wilson, C.J.N., Houghton, B.F., Kamp, P.J.J. and McWilliams, M.O., 1995. An exceptionally widespread ignimbrite with implications for pyroclastic flow emplacement. Nature, 378: 605-607

Wilson, L., 1980. Relationships between pressure, volatile content and ejecta velocity in three types of volcanic explosion. J Volcanol Geotherm Res, 8: 297-313

Woods, A.W. and Koyaguchi, T., 1994. Transitions between explosive and effusive eruptions of silicic magmas. Nature, 370: 641-644

Woods, A.W., 1995. A model for Vulcanian explosions. Nucl Eng Design, 155: 345- 
Wright, H.M.N., Roberts, J.J. and Cashman, K.V., 2006. Permeability of anisotropic tube pumice: Model calculations and measurements. Geophys Res Lett, 33(L17317). (doi)10.1029/2006GL027224.

Wright, H.M.N., Cashman, K.V., Gottesfeld, E.H. and Roberts, J.J., 2009. Pore structure of volcanic clasts: Measurements of permeability and electrical conductivity. Earth Planet Sci Lett, 280: 93-104. (doi)10.1016/j.epsl.2009.01.023.

Wright, H.M.N. and Weinberg, R.F., 2009. Strain localization in vesicular magma: Implications for rheology and fragmentation. Geology, 37: 1023-1026. (doi)10.1130/G30199A.1.

Zhang, Y., 1999. A criterion for the fragmentation of bubbly magma based on brittle failure theory. Nature, 402: 648-650 


\section{Figure Captions}
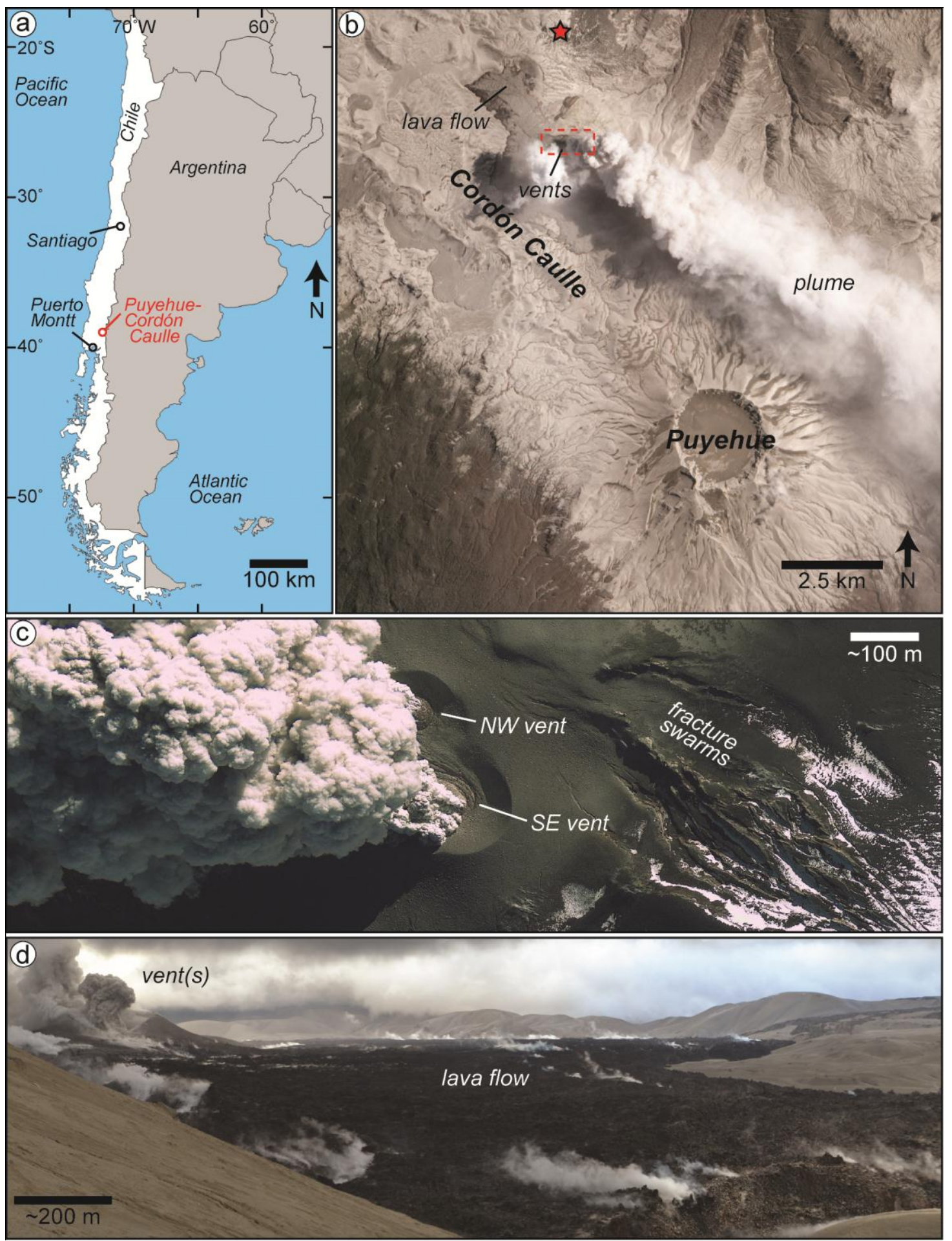

Fig.1: Location. a: Location of the Puyehue-Cordón Caulle Volcanic Complex,

Southern Andes, Chile. b: Satellite image of eruptive centre taken close to the time of observation on January 26, 2012, with key features marked. Image from the Advanced Land Imager on NASA's Earth Observing-1 (EO-1) satellite 
(http://earthobservatory.nasa.gov/NaturalHazards/view.php?id=77065); red star marks approximate observation point from which video footage was taken and from where the bombs were collected; red box shows region highlighted in panel c. c: overlapping vent structure, provided by GeoEye Foundation, taken with satellite GeoEye-1, on July 3. Although activity was more intense when the inset image was taken, it shows clearly the overlapping cone structure that had evolved into a single tephra cone by the time of our observations. d: Panorama of the active lava flow and NW vent as seen on Jan. 10, 2012, scale is approximate.

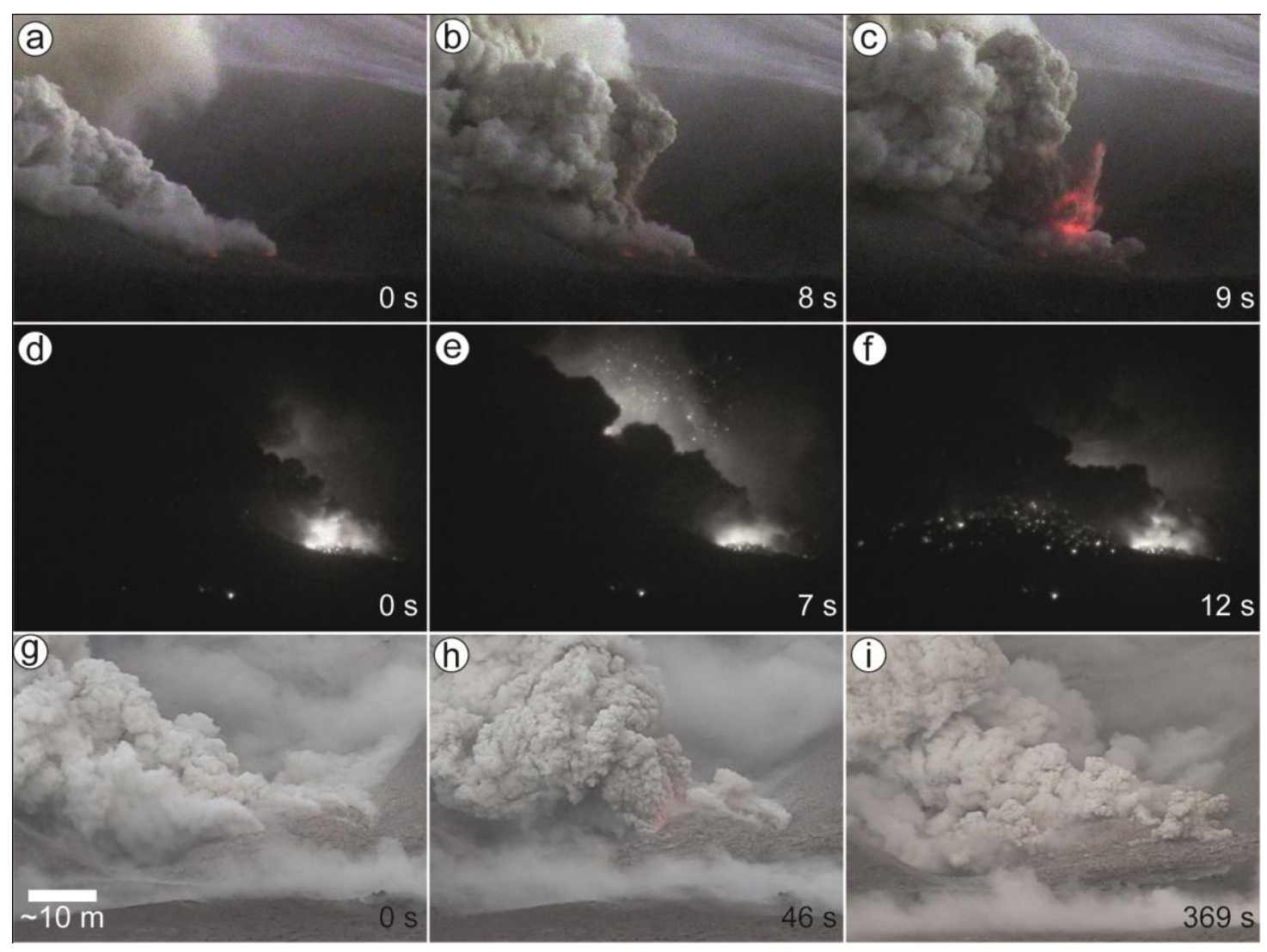

Fig. 2: Typical sequences of activity. Time of each frame relative to the first frame indicated in lower right hand corner. a-c: Sequence of activity types rapidly increasing in intensity from sub-vents of the NW crater observed in twilight conditions on Jan. 4. a) gas jetting from two obvious point sources; b) increase in gas jetting from left source, and transition to ash jetting from right source; c) incandescent bomb-forming 
Vulcanian blast simultaneously disrupting both point sources. d-f: Activity from NW and SE craters observed in IR video during the night of Jan. 4. d) low-intensity activity from NW crater, with slight glow visible from mostly-obscured SE crater; e) highintensity Vulcanian blast from SE crater, with little change in activity at the NW; f) bombs from SE crater deposited on cone. g-i: Sequence of increasing intensity in visible light during the day of Jan. 10. g) gas jetting from multiple sub-vent point sources; h) transition to ash jetting at central sub-vents, that coalesce into a single slotshaped outlet; i) brief opening of additional degassing point sources in arcuate failure ring around margin of the larger conduit structure.

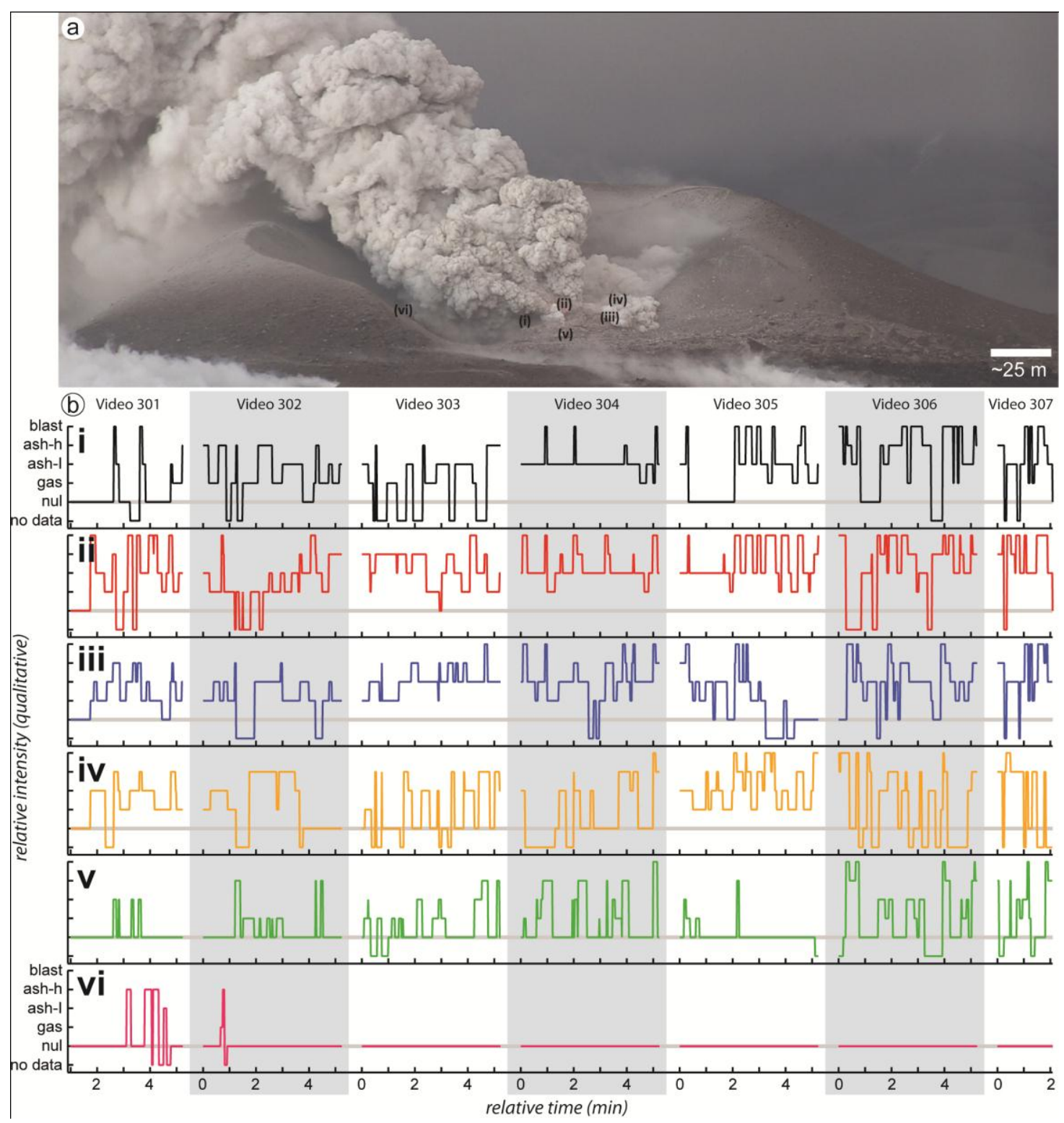


Fig. 3. Timelines of visible footage. a) Overview of the NW crater showing the series of six long-lived sub-vents (i-vi) from which activity was logged. Diameter of the cone at its base is $\sim 400 \mathrm{~m}$. Connection to the SE crater is obscured by the plume. $\mathrm{b}$ ) Timelines of activity. Timescale is divided into $7 \mathrm{x} \sim 5$ minute sections (Video 301307), corresponding to individual video clip lengths (but with $<\sim 30$ seconds between clips), and marked by alternating white and light grey regions. Scale of relative intensity is qualitative, based on visual observations (see text for description). Of the relative intensity designations, the most subjective is the division of the ash emission regime into two levels of relative intensity.
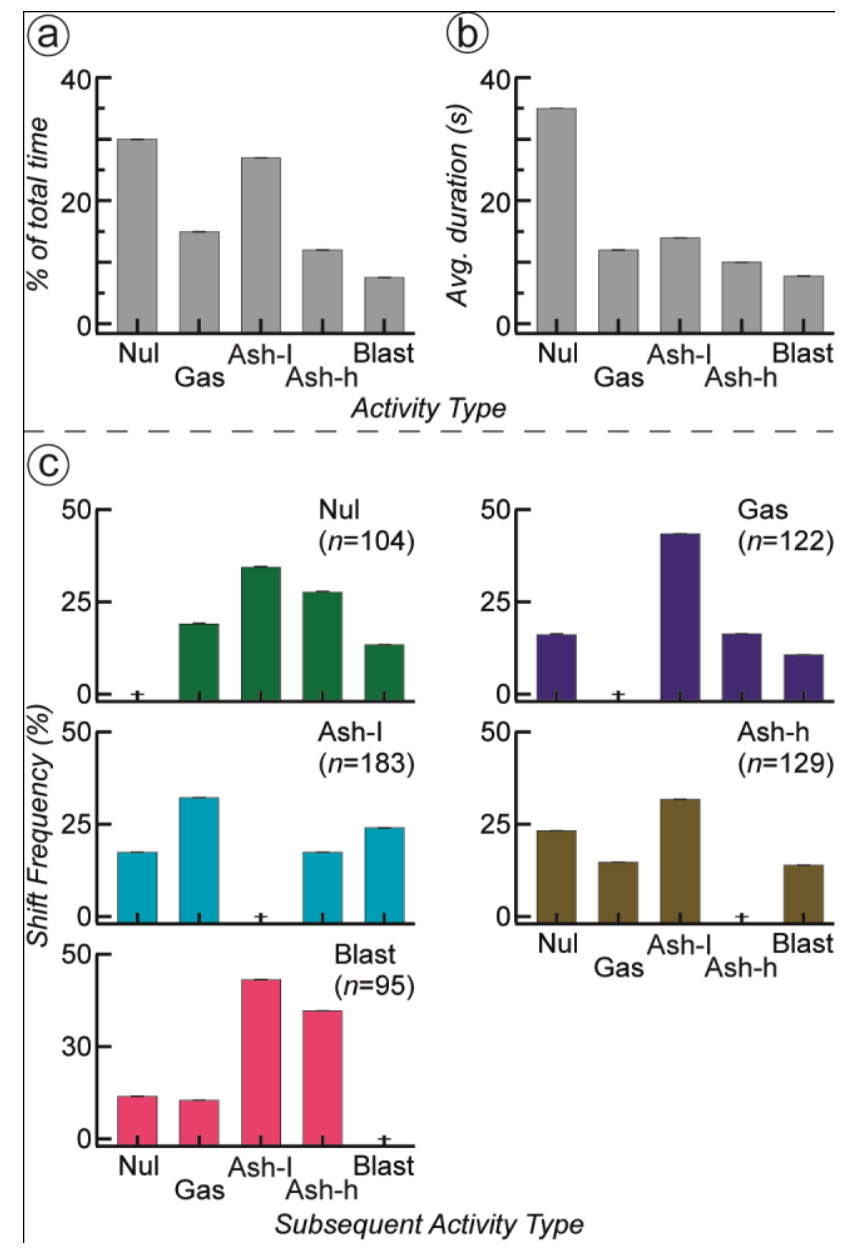

Fig. 4. Basic statistics on types of activity from sub-vents of the NW vent as seen in daylight. a) The total amount of time spent in each type of sub-vent activity, averaged over sub-vents i-v of Fig. 3. b) Average duration of individual sub-vent phases. c) 
Series of histograms showing evolution from each type of activity at sub-vents. Each panel represents one type of activity, and shows the frequency ( $\%$ for $n$ observed phases) of the type of activity that immediately followed.

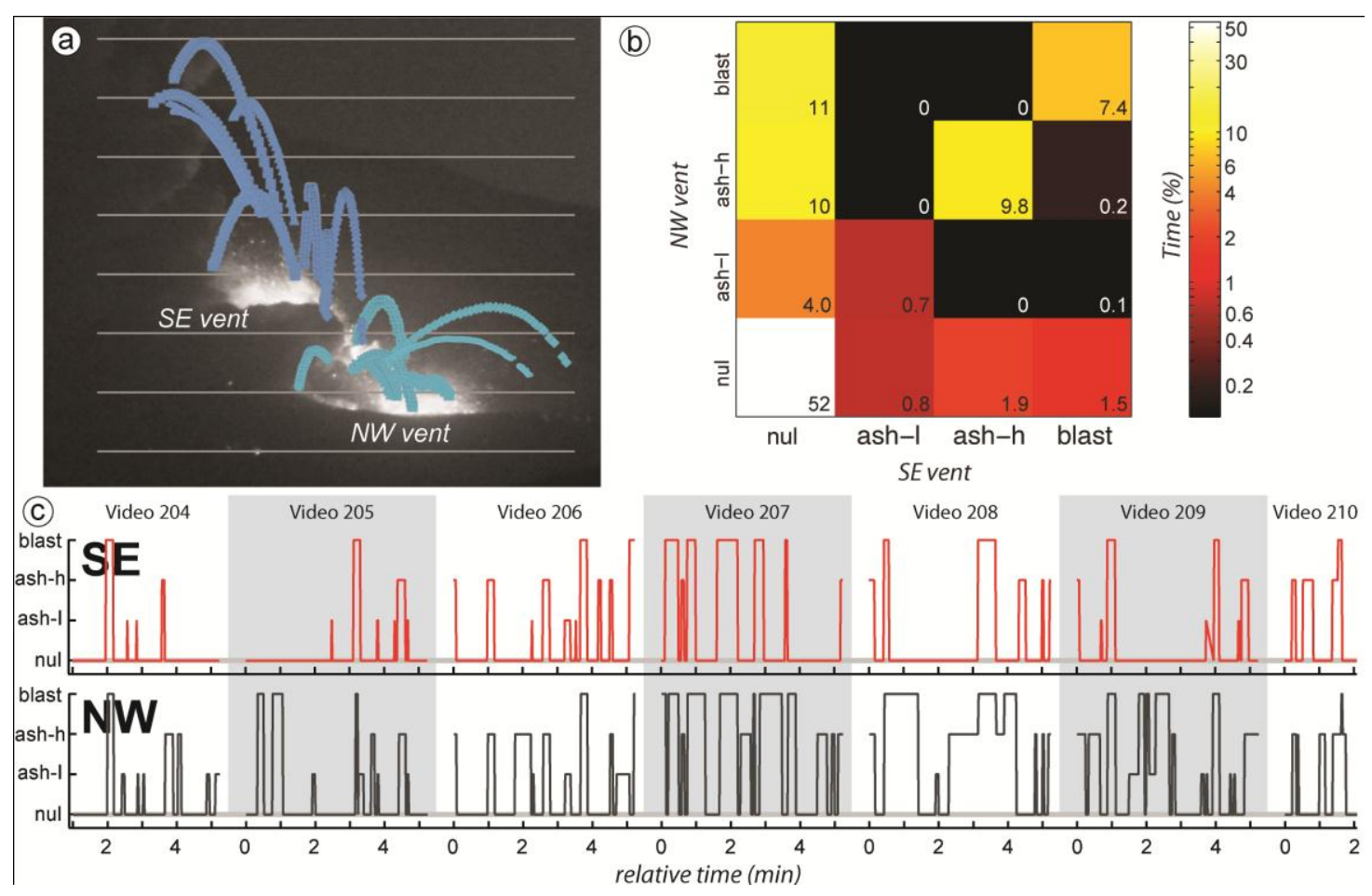

Fig. 5: IR footage. a) Tracked bomb trajectories from the SE and NW vents, showing clear difference between these regions of activity. b) Correlation statistics showing the percentage of time that the style of activity at one vent was associated with the style of activity at the other vent. c) Timelines of activity tracked from NW and SE vents, neglecting the known presence of sub-vents that cannot be discerned by night. Timescale and notation as in Figure 3. Note a different qualitative scale for the intensity of activity, limited to inactivity (nul), to detectable activity (possibly gas and/or ash jetting, ash-I), to minor activity that likely produced ash (ash-h), to Vulcanian blasts. 


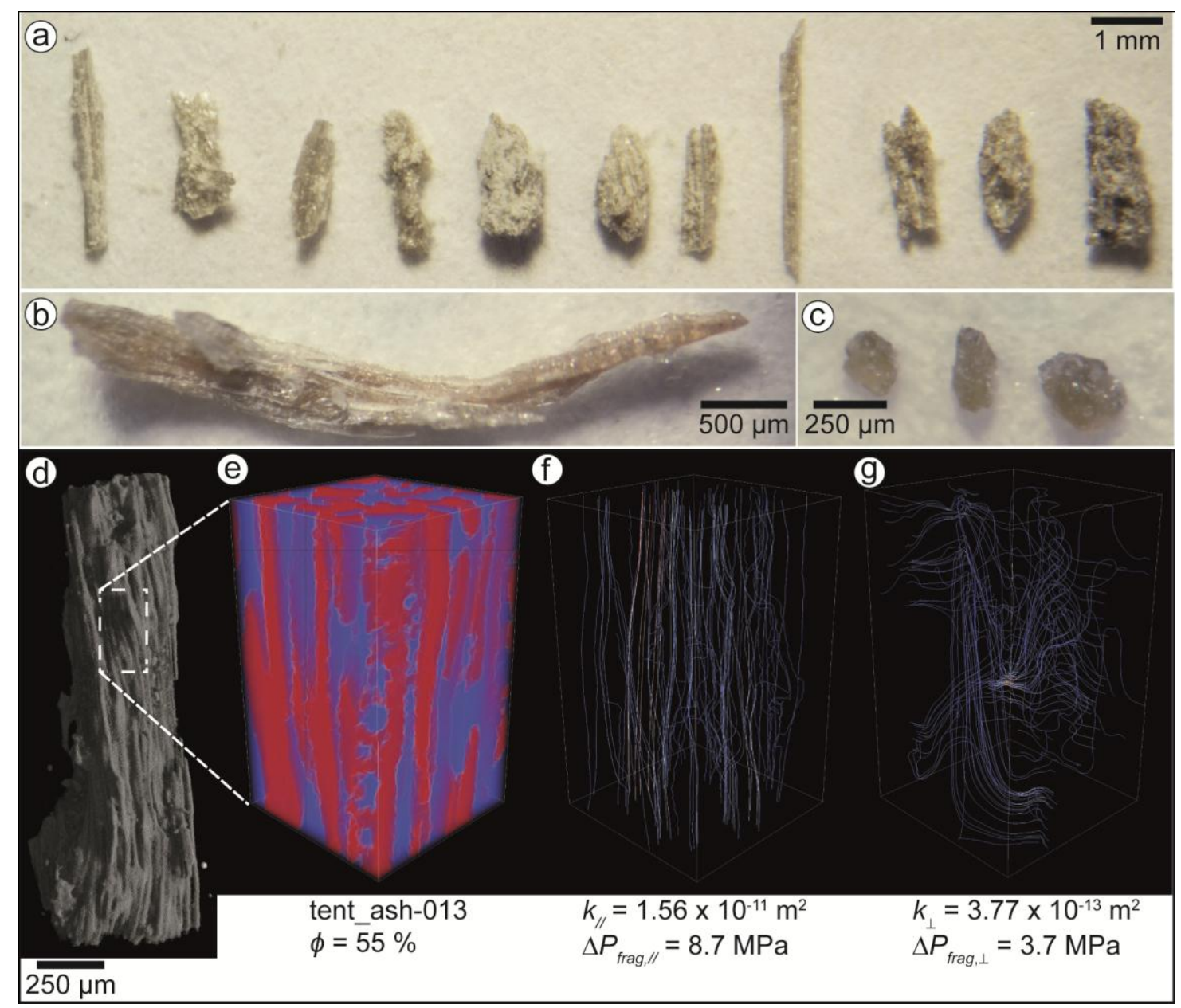

Fig. 6. Ash textures. a-c: Binocular microscope images of juvenile ash emitted during the night of January 4. a-b: microtubular pumice ash; c: dense ash. d-g: 3-D $\mu$-cT reconstructions of individual ash particle (tent_ash-013, Table 1). d) reconstruction of entire particle showing microtube structure (VGAStudio image); e) REV isolated for porosity and permeability measurements (Paraview Image, red is void space, blue is glass); f) streamlines of simulated gas flow through REV in fabric-parallel direction, colours represent relative gas velocities; g) streamlines in one fabric-normal direction. 


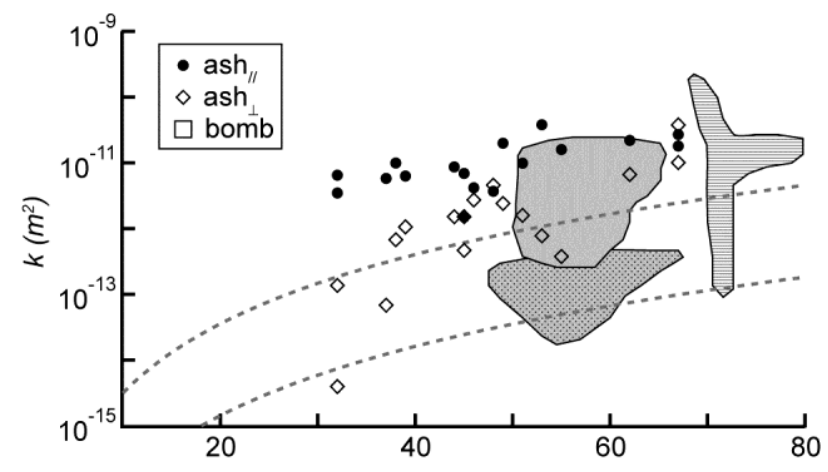

Fig. 7. Porosity $(\phi)$ versus permeability $(k)$ in fabric-parallel $(/ /)$ and fabric-

perpendicular $(\perp)$ directions for juvenile ash (Table 1). $k_{\perp}$ is plotted as average of two perpendicular calculations. Dashed lines represent range of data for silicic pumice given by Klug and Cashman (1996), grey and grey stippled fields represent $k_{/ /}$and $k_{\perp}$, respectively, for tube pumice from the Kos Plateau Tuff given by Degruyter et al. (2010b), hatched field represents $k_{/ /}$in tube pumice given by Wright et al. (2006). 


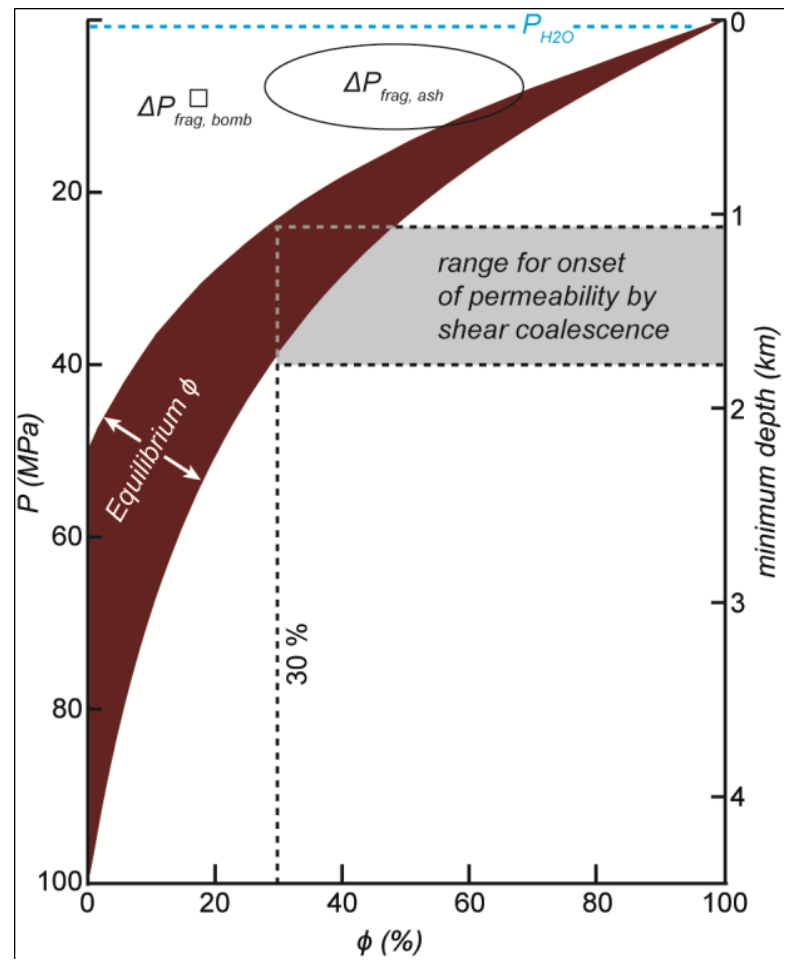

Fig. 8. Pressure $(P)$ versus porosity $(\phi)$ for Cordón Caulle magma. Pressures also expressed as minimum depths using density of dense magma, $\rho_{m}=2300 \mathrm{~kg} \mathrm{~m}^{-3}$. Envelope of equilibrium $\phi$ calculated following Burgisser and Gardner (2005), for the shallowest (50 MPa) and deepest (100 MPa) Cordón Caulle magma storage depths experimentally determined by Castro et al. (2013). Zero porosity at storage is assumed, as is $\mathrm{H}_{2} \mathrm{O}$ solubility following Henry's law, with constant $\kappa=3.5 \times 10^{-6} \mathrm{~kg}^{-0.5}$ $\mathrm{m}^{-0.5} \mathrm{~s}$ of a generic rhyolite (Newman and Lowenstern, 2002). Range of depths at which equilibrium porosity reaches $30 \%$ may be depth at which shear coalescence becomes important (Okumura et al., 2009), and thus may mark the depth to which subvent degassing structures penetrate. Also indicated are the ranges of $\Delta P_{\text {frag }}$ versus $\phi$ for the ash and bombs (Table 1), and the equilibration pressure of pyroclasts as indicated by their residual $\mathrm{H}_{2} \mathrm{O}$ contents $\left(P_{\mathrm{H} 2 \mathrm{O}}\right.$; equivalent for ash and bomb at scale of figure). Note that $P_{H 2 O} \ll<$ than the pressures suggested by equilibrium $\phi$ envelope indicates that open system degassing has occurred, and $P_{H 2 O}<\Delta P_{\text {frag }}$ indicates that fragmentation was not primarily by bubble overpressure. 


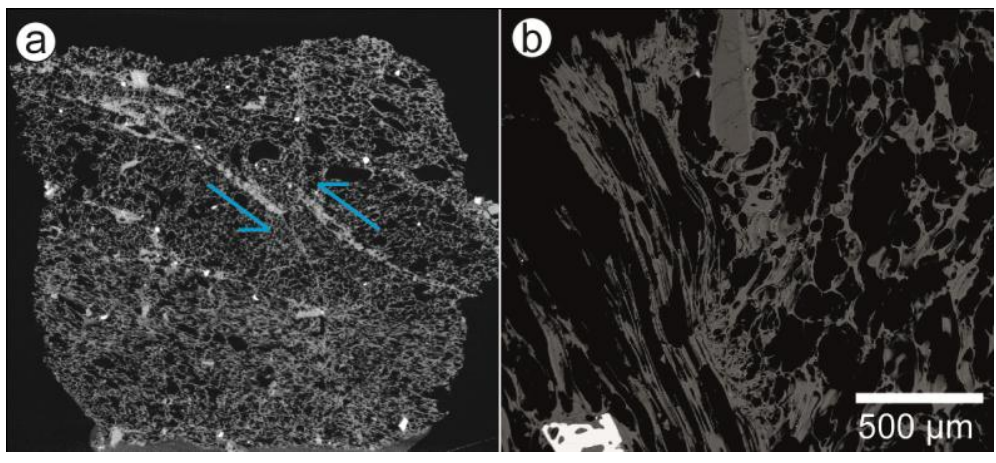

Fig. 9. Evidence for strain localization in the 2011-12 Cordón Caulle magma. a) $\mu$-cT image of a whole pumice lapillus showing shortened and offset bands defined by dense glass and crystal fragments. b) SEM image of adjacent tubular (left) and isotropic (right) vesicle networks in a single pumice lapillus. Note that these samples were collected by the authors during the Plinian phase of the eruption, in July 2011, not during the observed activity in which sampling was limited to the collection of fine ash. They are shown here as evidence that fine scale strain localization occurred early in the Cordón Caulle eruption, and may have been an incipient form of shear localization that eventually led to the development of large scale degassing structures. 


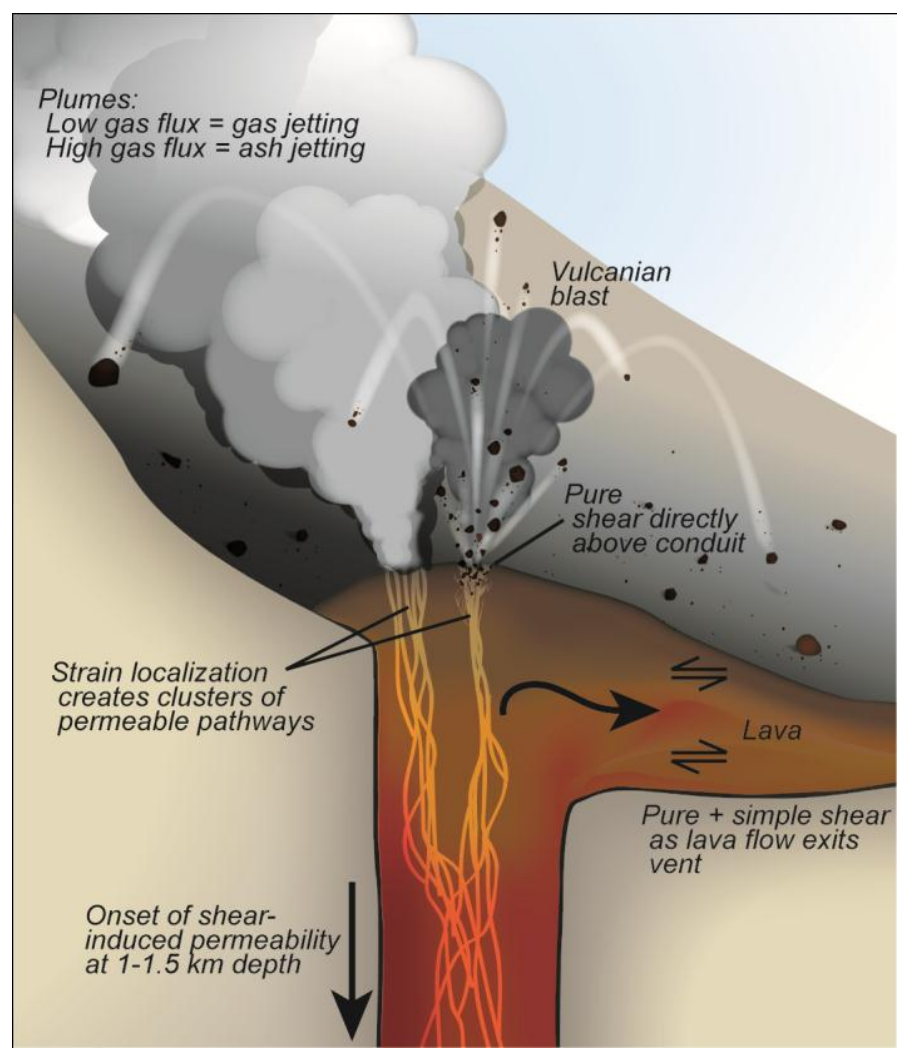

Fig. 10. Cartoon (not to scale) of cross-sectional view through the shallow vent and upper conduit of Cordón Caulle during the observed hybrid activity. 


\section{Tables}

Table 1 . Porosity and permeability of pyroclasts

\begin{tabular}{|c|c|c|c|c|c|c|c|c|c|}
\hline & $\begin{array}{c}\text { Resolution } \\
\left(\mu m p x^{-1}\right)\end{array}$ & $\begin{array}{c}\phi \\
(\%)\end{array}$ & $k_{/ /}$ & $\begin{array}{c}\text { Permeability } \\
\left(m^{2}\right) \\
k_{\perp l}\end{array}$ & $k_{\perp 2}$ & $\begin{array}{l}\Delta P_{\text {frag }} / / \\
(M P a) \\
\end{array}$ & $\begin{array}{r}\Delta P_{\text {frag } \perp} \\
(M P a) \\
\end{array}$ & $\begin{array}{c}\mathrm{H}_{2} \mathrm{O} \\
(w t \%)\end{array}$ & $\begin{array}{c}P_{\mathrm{H} 2 \mathrm{O}} \\
(\mathrm{MPa})\end{array}$ \\
\hline Ash & & & & & & & & 0.14 & 0.19 \\
\hline tent-02A & 2.25 & 39 & 6.3E-12 & $2.2 \mathrm{E}-13$ & $1.9 \mathrm{E}-12$ & 9.3 & 6.1 & & \\
\hline tent-03 & 0.77 & 38 & $1.0 \mathrm{E}-11$ & $1.1 \mathrm{E}-12$ & $3.0 \mathrm{E}-13$ & 10.9 & 5.8 & & \\
\hline tent-04 & 0.71 & 46 & $4.2 \mathrm{E}-12$ & $1.9 \mathrm{E}-12$ & 3.6E-12 & 6.9 & 6.2 & & \\
\hline tent-06 & 1.30 & 49 & $2.0 \mathrm{E}-11$ & $1.2 \mathrm{E}-12$ & 3.6E-12 & 10.5 & 5.7 & & \\
\hline tent-10 & 0.92 & 32 & $3.5 \mathrm{E}-12$ & $3.1 \mathrm{E}-15$ & $4.8 \mathrm{E}-15$ & 9.7 & 5.0 & & \\
\hline tent-11 & 0.75 & 32 & $6.5 \mathrm{E}-12$ & 2.3E-13 & 4.1E-14 & 11.4 & 5.8 & & \\
\hline tent-13 & 0.77 & 55 & $1.6 \mathrm{E}-11$ & 4.4E-13 & $3.1 \mathrm{E}-13$ & 8.7 & 3.7 & & \\
\hline tent-14 & 0.77 & 62 & $2.2 \mathrm{E}-11$ & 3.4E-12 & $1.0 \mathrm{E}-11$ & 8.7 & 5.9 & & \\
\hline tent-15 & 0.77 & 51 & $9.9 \mathrm{E}-12$ & $2.2 \mathrm{E}-12$ & $1.0 \mathrm{E}-12$ & 8.2 & 5.1 & & \\
\hline tent-16 & 0.77 & 53 & $3.8 \mathrm{E}-11$ & $1.5 \mathrm{E}-12$ & $1.4 \mathrm{E}-14$ & 12.5 & 4.3 & & \\
\hline tent-18 & 0.77 & 67 & 2.7E-11 & 8.9E-12 & 1.1E-11 & 8.7 & 6.2 & & \\
\hline tent-19 & 0.77 & 45 & $1.5 \mathrm{E}-12$ & $5.3 \mathrm{E}-13$ & 4.1E-13 & 5.7 & 4.7 & & \\
\hline tent-20 & 0.75 & 44 & 8.7E-12 & 1.6E-12 & 1.4E-12 & 9.0 & 5.8 & & \\
\hline tent-21 & 0.94 & 37 & $5.8 \mathrm{E}-12$ & 8.7E-14 & $5.0 \mathrm{E}-14$ & 9.5 & 4.7 & & \\
\hline tent-22 & 0.94 & 45 & $6.9 \mathrm{E}-12$ & $8.5 \mathrm{E}-13$ & 2.2E-12 & 8.1 & 5.6 & & \\
\hline tent-23 & 1.00 & 48 & 3.7E-12 & $5.1 \mathrm{E}-12$ & 4.0E-12 & 6.4 & 6.8 & & \\
\hline tent-24 & 1.00 & 67 & $1.8 \mathrm{E}-11$ & $3.2 \mathrm{E}-11$ & $4.4 \mathrm{E}-11$ & 7.4 & 9.8 & & \\
\hline \multicolumn{10}{|l|}{$\begin{array}{c}\text { Bomb } \\
\text { Rim }\end{array}$} \\
\hline VB-01 & 14.6 & 17 & nul & nul & nul & $\mathrm{N} / \mathrm{A}$ & 9.1 & $0.2-0.25$ & $0.37-0.54$ \\
\hline
\end{tabular}

Porosity $(\phi)$ calculated by thresholding $\mu$-cT scans in ImageJ; permeability $(k)$

calculated with lattice Boltzmann simulations following Degruyter et al. (2010a);

fragmentation overpressure $\left(\Delta P_{\text {frag }}\right)$ calculated by $\Delta P_{\text {frag }}=\frac{8.21 \times 10^{5} \sqrt{k}+1.54}{\phi}$

following Mueller et al. (2008); bulk $\mathrm{H}_{2} \mathrm{O}$ measured by KFT, with $\mathrm{H}_{2} \mathrm{O}$ equilibration

pressures $\left(P_{H 2 O}\right)$ determined by VolatileCalc (Newman and Lowenstern, 2002). 